\title{
Invasive characteristics of human prostatic epithelial cells: understanding the metastatic process
}

\author{
CA Hart', M Brown ${ }^{*, 1}$, S Bagley ${ }^{2}$, M Sharrard ${ }^{3}$ and NW Clarke ${ }^{1,4,5}$ \\ 'PromPT Genito-Urinary Cancer Research, Cancer Research UK Paterson Institute for Cancer Research, Christie Hospital NHS Trust, Wilmslow Road, \\ Manchester M2O 4BX, UK; ${ }^{2}$ Advanced Imaging Facility, Cancer Research UK, Paterson Institute for Cancer Research, Christie Hospital NHS Trust, \\ Wilmslow Road, Manchester M20 4BX, UK; ${ }^{3}$ YCR Cancer Research Unit, Biology Department, The University of York, York YO 105 YW, UK; \\ ${ }^{4}$ Department of Urology, Salford Royal Hospital, Eccles Old Road, Salford, UK; ${ }^{5}$ Christie Hospital NHS Trust, Wilmslow Road, Manchester, UK
}

\begin{abstract}
Prostate cancer has a predilection to metastasise to the bone marrow stroma (BMS) by an as yet uncharacterised mechanism. We have defined a series of coculture models of invasion, which simulate the blood/BMS boundary and allow the elucidation of the signalling and mechanics of trans-endothelial migration within the complex bone marrow environment. Confocal microscopy shows that prostate epithelial cells bind specifically to bone marrow endothelial-to-endothelial cell junctions and initiate endothelial cell retraction. Trans-endothelial migration proceeds via an epithelial cell pseudopodial process, with complete epithelial migration occurring after $232 \pm 43 \mathrm{~min}$. Stromal-derived factor-I (SDF-I)/CXCR4 signalling induced PC-3 to invade across a basement membrane although the level of invasion was 3.5-fold less than invasion towards BMS $(P=0.0007)$ or bone marrow endothelial cells $(P=0.004)$. Maximal SDF-I signalling of invasion was completely inhibited by $10 \mu \mathrm{M}$ of the SDF-I inhibitor TI 40 . However, $10 \mu \mathrm{M}$ TI 40 only reduced invasion towards BMS and bone marrow endothelial cells by $59 \%(P=0.00 \mathrm{I})$ and $29 \%(P=0.0 \mathrm{I} I)$, respectively. This study highlights the need to examine the potential roles of signalling molecules and/or inhibitors, not just in single-cell models but in coculture models that mimic the complex environment of the bone marrow.

British Journal of Cancer (2005) 92, 503-5 I2. doi: I0.1038/sj.bjc.6602325 www.bjcancer.com

Published online 25 January 2005

(C) 2005 Cancer Research UK
\end{abstract}

Keywords: prostate; metastasis; CXCR4; bone marrow; endothelium

Prostate cancer $(\mathrm{CaP})$ is a widely prevalent disease (Thompson et al, 2004) but not all men go on to develop metastases. To do this, it is essential for tumour cells to migrate within the blood and lymphatic system. This is known to occur in other cancers (Taubert et al, 2004) and in many men with malignancy in the prostate and in other genito-urinary cancers (McIntyre et al, 2000; Meye et al, 2002). However, the presence of circulating cells per se does not necessarily lead to metastasis formation (Hood and Cheresh, 2002). The reasons for this are unclear at the present time. There is an urgent imperative to gain a better understanding of this process for two simple reasons. Firstly, men who develop bone metastases from $\mathrm{CaP}$ will almost invariably die from their disease in the absence of an intercurrent illness. Secondly, there are large numbers of men with a diagnosis of $\mathrm{CaP}$ whose disease will remain localised for long periods of time but who are currently being treated aggressively, with inevitable and perhaps unnecessary comorbidity.

The mechanism of metastasis is a complex multistage process that is only beginning to be understood. Initial steps include the loss of cell-to-cell adhesion within the tumour by downregulation of molecular binding complexes such as the E-cadherin/ $\beta$-catenin complex (Umbas et al, 1997; Bryden et al, 2002) and intravasation

*Correspondence: Dr M Brown; E-mail: mbrown@picr.man.ac.uk Received 14 October 2004; revised 9 November 2004; accepted 19 November 2004; published online 25 January 2005 of tumour cells through the basement membrane by production of enzymes such as matrix metalloproteinases (Hart et al, 2002). Once in the peripheral blood, the circulating tumour cell has to bind at its preferred metastatic site and invade through the local endothelial barrier to gain access to the underlying stroma (Scott et al, 2001) where it can then become established (Lang et al, 1997, 1998). We have shown previously that prostate epithelial cells preferentially bind to bone marrow endothelial cells in an integrin $\beta 1$-dependent manner, and that only malignant prostate epithelial cells invade in response to bone marrow endothelial cells (Scott et al, 2001). However, the specific mechanisms of invasion through the bone marrow endothelial barrier and the stimuli for that invasion are as yet undefined. There is therefore a need for better understanding of this process using in vitro models, to allow the identification of the stages and individual components underpinning the metastatic process. Such in vitro models would also provide invaluable preclinical tools for the evaluation of new anticancer therapies.

Recent studies have shown that many epithelial cancers metastasise preferentially to the bony skeleton. These include cancers of the prostate (Taichman et al, 2002), kidney (Schrader et al, 2002), lung (Burger et al, 2003) breast (Muller et al, 2001) and skin (Robledo et al, 2001; Murakami et al, 2002). Cells from these tumour types share many of the trafficking characteristics of haematopoietic stem cells (HSC) (Muller et al, 2001). The homing of the HSC to the bone marrow during foetal life and after bone marrow transplantation has been well characterised. The key 
molecular axis for this homing has been shown to involve the CXC chemokine stromal-derived factor-1 (SDF-1 or CXCL12) and its receptor CXCR4 (CD186). This model is supported by the facts that both bone marrow endothelial cells and osteoblasts express SDF-1 (Aiuti et al, 1997; Hamada et al, 1998; Ponomaryov et al, 2000), CXCR4 knockouts do not show haematopoietic engraftment of the bone marrow (Aiuti et al, 1999) and that the level of CXCR4 expression by HSC determines their ability to engraft the bone marrow (Peled et al, 1999). It has been shown recently that the CXCR4/CXCL12 axis also plays a crucial role in the targeting of several solid tumour metastases, including breast (Muller et al, 2001) kidney (Staller et al, 2003), lung (Burger et al, 2003), pancreas (Koshiba et al, 2000) and CaP (Taichman et al, 2002; Sun et al, 2003) to the bone marrow. It has been shown in vitro that CXCR4 and CXCL12 interactions alongside CCR7/CCL21 interactions trigger pseudopodial invasion by malignant breast epithelial cells by actin polymerisation (Muller et al, 2001).

The CXCR4/CXCL12 axis is therefore a potential target for therapeutic intervention in malignancies that metastasise specifically to the bone marrow. Neutralisation of CXCR4 with monoclonal antibodies in non-Hodgkin's lymphoma models has been proven to be effective in preventing pseudopodial formation and trans-endothelial migration in vitro and to protect against tumour challenge in vivo, reducing existing tumour growth while preventing tumour extravasation (Bertolini et al, 2002). In this study, we have adapted existing bone marrow invasion models to represent the blood/BMS (BMS) barrier more closely and we have used these to follow malignant prostate epithelial invasion of the bone marrow compartment. Using these models, we have also evaluated the ability of the small peptide inhibitor of CXCR4, T140 (Tamamura et al, 2001) to inhibit prostatic invasion in vitro.

\section{MATERIAL AND METHODS}

\section{Materials}

All general reagents were purchased from Sigma-Aldridge, Poole, UK. Tissue culture medium and horse serum was from Invitrogen, Paisley, UK with the exception of Ham's F12 media, PAA Laboratories, Austria and EBM-2 Bullet kit from Cambrex Bio Science Ltd, Berkshire, UK. Foetal calf serum (FCS) was supplied by Labtech International Ltd., Uckfield, East Sussex, UK. Matrigel ${ }^{\mathrm{B}}$ Basement Membrane Matrix and $8 \mu \mathrm{M}$ cell culture inserts were from Becton Dickinson Labware, NJ, USA and Worthington trypsin and collagenase type I from Lorne Laboratories Ltd, Twyford, UK. T140 anti CXCR4 peptide was a kind gift from Professor Nobutaka Fujii, Graduate School of Pharmaceutical Sciences, Kyoto University, Sakyo-ku, Kyoto, Japan.

\section{Antibodies}

Mouse anti-human pan cytokeratin was from Sigma-Aldridge, Poole, UK; rabbit anti-mouse biotinylated antibody from DAKO Ltd,. Cambridge, UK and Vectastain Elite ABC kit from Vector Laboratories, CA, USA. CXCR4 clone 12G5 pure and PE conjugate and control IgG2a PE were from BD Biosciences Pharmingen, Oxford, UK.

\section{Cell lines}

The prostate cell lines PC-3 (Kaighn et al, 1979) and PNT2-C2 (Berthon et al, 1995) were cultured in Ham's F12, 7\% FCS and $2 \mathrm{mM} \mathrm{L}$-glutamine and in RPMI 1640, 10\% FCS and $2 \mathrm{mM} \mathrm{L}$ glutamine, respectively. PC3-GFP were cultured as standard PC-3 cells but with the addition of Hygromycin B $\left(0.15 \mathrm{mg} \mathrm{ml}^{-1}\right)$ (Sharrard and Maitland, 2000). Cultures were grown at $37^{\circ} \mathrm{C}$ in a humidified atmosphere of $5 \% \mathrm{CO}_{2}$ in air.
The bone marrow endothelial cell line (BMEC) (Almeida-Porada and Ascensao, 1996) was a gift from Dr Gracia Almeida-Porada (University of Nevada, Reno NV, USA). Bone marrow endothelial cell lines were cultured in EBM-2 Bullet kit/15\% FCS and $2 \mathrm{mM} \mathrm{L}-$ glutamine (EGM-2). Bone marrow endothelial cell line flasks were precoated prior to cell culture by incubation at $37^{\circ} \mathrm{C}$ for $1 \mathrm{~h}$ with $50 \mu \mathrm{g} \mathrm{ml}^{-1}$ of fibronectin in PBS. Cultures were grown at $37^{\circ} \mathrm{C}$ in a humidified atmosphere of $5 \% \mathrm{CO}_{2}$ in air and used up to passage 20. All cell lines were removed from tissue culture flasks by treatment with Trypsin-EDTA.

\section{Long-term human bone marrow}

Bone marrow stroma was cultured from female human ribs removed during routine surgery, after informed consent, for nonmalignant renal disease. Preparation for tissue culture used the method of Coutinho et al, 1993. Briefly, bone marrow cells were flushed from the rib, resuspended in long-term culture medium (Iscove's modified Dulbecco's medium, 10\% FCS, 10\% horse serum and $5 \times 10^{-7} \mathrm{M}$ hydrocortisone) before $2 \times 10^{7}$ cells were plated into $25 \mathrm{~cm}^{2}$ tissue culture flasks. The cultures were grown at $33^{\circ} \mathrm{C}$ in $5 \% \mathrm{CO}_{2}$ in air for $4-5$ weeks until haemopoietically active areas were observed. All cells were removed from tissue culture flasks by treatment with trypsin-EDTA.

\section{Primary prostate epithelial cell cultures}

With informed consent prostatic tissue was obtained from male subjects undergoing trans-urethral resection for bladder outflow obstruction arising from $\mathrm{CaP}$ or benign prostatic hyperplasia (BPH). Each individual prostate chip was bisected for histological diagnostic evaluation and for tissue culture. Prostate epithelial cells and fibroblasts were isolated by collagenase digestion followed by differential centrifugation (Lang et al, 1998). Epithelial cells were grown in flasks in keratinocyte-SFM at $37^{\circ} \mathrm{C}$ in a humidified atmosphere of $5 \% \mathrm{CO}_{2}$ in air and then used at passage $1-3$. All cells were removed from tissue culture flasks by treatment with trypsin-EDTA.

\section{Measurement of invasion through BMEC using confocal microscopy}

This was carried out using time lapse confocal microscopy measurements. Bone marrow endothelial cell line cells were grown on autoclaved glass coverslips $(40 \mathrm{~mm})$ precoated with fibronectin $\left(50 \mu \mathrm{g} \mathrm{ml}^{-1}\right)$ until confluent. The coverslip was then washed and mounted in a Bioptechs FC2 heated chamber closed to the external environment containing EGM-2 media. In all, $5 \times 10^{5}$ PC3-GFP cells in EGM-2 were added and allowed to bind for $1 \mathrm{~h}$, after which any unbound cells were removed and fresh EGM-2 added. The Bioptechs FC2 closed chamber system with both chamber and objective temperature control was then mounted onto a Zeiss LSM510 based around an AxioVert $100 \mathrm{M}$. An argon $25 \mathrm{~mW}$ (Coherent) laser was employed for GFP excitation $(458 \mathrm{~nm}$ excitation, $505 \mathrm{~nm}$ long-pass filter, laser power $3 \%$ transmittance) and simultaneous brightfield phase microscopy. Employing a $\times 63$ Plan-Apochromat 1.4 NA oil/phase objective lens, images were captured at a resolution of $512 \times 512$ pixels with a pixel dwell time of $1.76 \mu \mathrm{s}$. The detector pinhole was set to one airy unit with a stage motor resolution of $1 \mu \mathrm{M}$. Visualisation of the data sets was carried out from coverslip to top of the BMEC layer every 30 min over $10 \mathrm{~h}$.

Scoring of data was performed using the Zeiss LSM Image browser viewing time $v s$ three-dimensional (3D) axis. A GFPpositive cell was scored as to its position in relation to the BMEC cell layer (Table 1). A '+' score was recorded if a cell made contact with the glass coverslip. 
Table I Time taken (min) for PC3-GFP cells to invade through the BMEC layer and the percentage of test cells that attained this

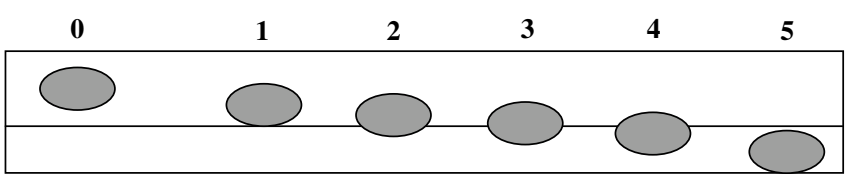

Time (min)

\begin{tabular}{lcccc} 
& Stage I & Stage 2 & $\mathbf{+}$ & Stage 5 \\
\hline Mean $(n=38)$ & 90 & 136 & 170 & 232 \\
Std error $( \pm)$ & 13 & 17 & 20 & 43 \\
\% Cells & 100 & 65 & 68 & 29 \\
\hline
\end{tabular}

Key: PC3-GFP cell volume penetrating upper surface of BMECs: $0=$ unbound; I = bound; $2=25 \%$ volume invaded; $3=50 \%$ volume invaded; $4=75 \%$ volume invaded; $5=100 \%$ total invasion; $+=$ any part of the cell makes contact with the coverslip.

\section{Cellular invasion assay}

Migration of seeded epithelial cells across Matrigel and endothelial cell barriers was measured objectively in invasion chambers. Cell culture inserts ( $8 \mu \mathrm{m}$ pore size), coated with Matrigel diluted $1: 25$ with Dulbecco's modified Eagle's media (DMEM), were placed in a 24-well plate containing $1 \mathrm{ml}$ of DMEM/0.1\% bovine serum albumin (BSA) with either tissue culture plastic (TCP), BMS or BMEC at the base. PC-3, PNT2-C2, CaP or BPH epithelial cells $\left(1 \times 10^{5}\right.$ cells in $0.25 \mathrm{ml}$ of DMEM/0.1\% BSA) were seeded on to the top of the inserts. T140 (10 $\mu \mathrm{M}$ made up in distilled water) was added to the media containing PC-3 cells $30 \mathrm{~min}$ prior to plating in the assay. The cells were then incubated at $37^{\circ} \mathrm{C}$ for $18 \mathrm{~h}$. The inserts were removed, washed in PBS and the noninvading cells together with the Matrigel removed from the insert by wiping with a cotton bud. Inserts were then fixed and stained in $2 \%$ crystal violet $/ 20 \%$ methanol and air-dried. Cells on the bottom of the insert were counted according to the manufacturer's instructions. Each experiment was carried out in duplicate.

An endothelial barrier was formed by confluent BMEC cells cultured on top of Matrigel within the insert. For this, assay inserts were fixed in methanol/acetone $(1: 1)$ prior to staining with mouse anti-human pan cytokeratin $(1: 200)$ followed by biotinylated rabbit anti-mouse secondary antibody $(1: 400)$. This was then visualised by incubation with streptavidin-HRP complex and DAB substrate prior to counter staining with haematoxylin.

\section{Immunohistochemistry}

Prostate chips were obtained from consenting male subjects undergoing surgery for bladder outflow obstruction from malignant $(\mathrm{CaP})$ or nonmalignant $\mathrm{BPH}$. The tissue was fixed in formalin, paraffin embedded and sectioned. Prostatic bone marrow metastases from $8 \mathrm{~mm}$ trephine core iliac crest biopsies taken with informed consent from men undergoing subcapsular orchidectomy for untreated $\mathrm{CaP}$ were sectioned and undecalcified. The paraffin-embedded sections were first dewaxed followed by citrate antigen retrieval. Samples were stained with IgG, anti-pan cytokeratin $(1: 200)$ and CXCR4 $\left(5 \mu \mathrm{g} \mathrm{ml}^{-1}\right)$ according to protocols given above.

\section{Flow cytometry/CXCR4 analysis}

The cell lines PC-3, PNT2-C2 and epithelial cells from patients with $\mathrm{CaP}$ or $\mathrm{BPH}$ (cultured as described above and used at passage 1) were fixed with $4 \%$ formaldehyde/PBS and labelled with CXCR4 PE conjugate in PBS. Cells were analysed using a FACScan flow cytometer (Becton Dickinson). PE was excited at $488 \mathrm{~nm}$ and the emission was detected at $565 \pm 15 \mathrm{~nm}$ band pass. At least 50000 events were analysed to achieve a significant population for analysis. Analysis of results was performed using WinMDI 2.8 .

\section{RESULTS}

\section{Measurement of PC3-GFP invasion through BMEC}

Previously, Scott et al (2001) found that CaP cells bind to BMS and bone marrow endothelial primary cells (BME) in preference to TCP, human umbilical vein endothelial cell line (HUVEC) and prostate fibroblasts. To examine this phenomenon more closely, with particular reference to binding and invasion, we used the GFP-transfected PC-3 cell line in conjunction with BMEC using confocal microscopy. We found that most of the PC3-GFP cells bound within $60 \mathrm{~min}$ and further to Scott et al (2001), we found

\section{A}

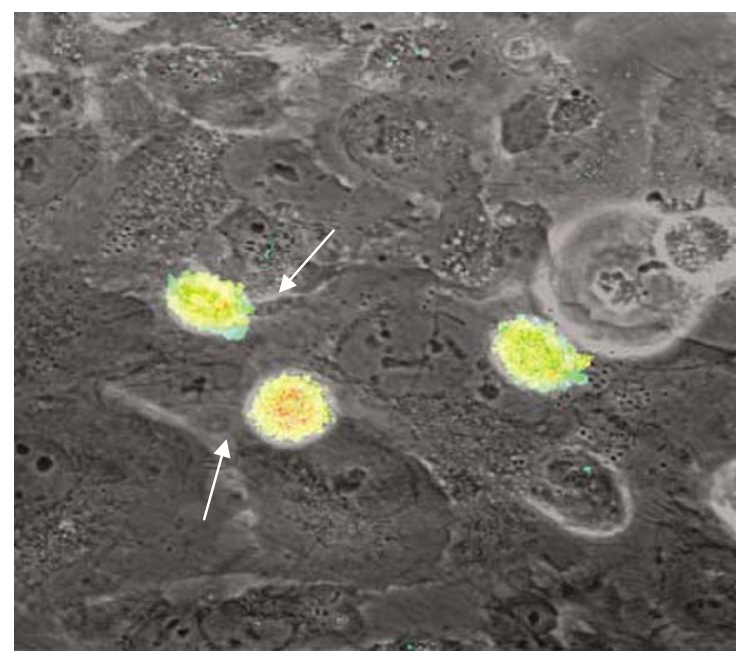

B

(a)
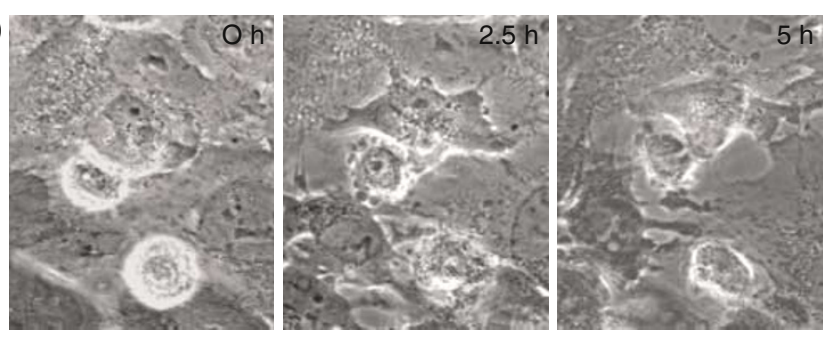

(b)
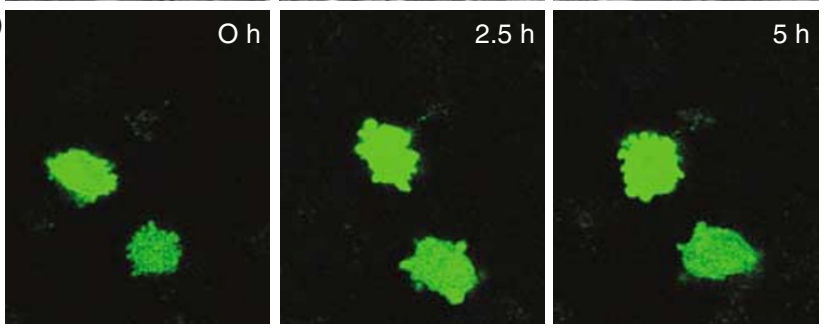

Figure I (A) PC3-GFP cells after $60 \mathrm{~min}$ in culture with BMEC cells. Arrows indicate the joints between endothelial cells. (B) (a) Confocal time lapse of PC3-GFP cells interacting with BMEC monolayer showing endothelial cell retraction (arrowed) over a $5 \mathrm{~h}$ time frame. (b) Corresponding fluorescent confocal time lapse of PC3 GFP cells. 
that they had a marked tendency to bind at endothelial junctional regions $(86.26 \pm 7.12 \% ; P=0.003)$. Figure $1 \mathrm{~A}$ shows three PC3-GFP cells at their binding sites after $60 \mathrm{~min}$ in contact with the BMEC. Each endothelial cell can be distinguished clearly and the arrows indicate the junctions at areas where each of the PC3-GFP cells were bound.

These cells were studied using time-lapse confocal microscopy over a $10 \mathrm{~h}$ period taking a series of $\mathrm{Z}$ slices through the PC3-GFP and BMEC layer every $30 \mathrm{~min}$ to obtain a $3 \mathrm{D}$ image. Figure $1 \mathrm{~B}$ shows BMEC retraction postbinding of the PC3-GFP cell. At $2.5 \mathrm{~h}$ postepithelial binding, there is significant endothelium retraction (indicated by arrows) along two sides of the invading epithelial cell with almost complete retraction of the surrounding endothelial cells after $5 \mathrm{~h}$. During this period, the epithelial cell remains in contact with one of the endothelial cells.

Figure $2 \mathrm{~A}$ shows the raw unprocessed image of PC3-GFP cells over a period of $7.5 \mathrm{~h}$ showing one Z-plane image. For an initial evaluation of the data, a height coded $3 \mathrm{D}$ image was generated at each time point via the LSM510 software. Depending on the location in the axial dimension, pixels were pseudocoloured to generate a two-dimensional image map. By analysing multiple Zplane images for each time point, the GFP signal could be tracked and shown as depth (Figure 2B). Blue indicates $25 \mu \mathrm{M}$ (top of endothelial layer) down to red $0 \mu \mathrm{M}$ (base of endothelial layer/ coverslip). Over time, the interactions of the PC3-GFP cells with the endothelial layer can be tracked. The bottom cell in this image can be seen to move from pale blue through to green, at which point a small pseudopodial process can be seen to extend downwards to the coverslip (red) and extend outwards along the bottom while the rest of cell remains green. At $210 \mathrm{~min}$, this body is drawn down (red colour) below the BMEC layer. Figure $2 \mathrm{C}$ shows this cell as a $3 \mathrm{D}$ axial projection. The dashed area represents a visualisation of the volume taken by the endothelial cells (this excludes representation of endothelial joints). Figure 2D shows this cell after further processing. Image analysis was carried out by applying a median filter $3 \times 3 \times 3$ to remove noise. The data were then imported into Imaris (Bitplane AG) where an isosurface was created, a process of $3 \mathrm{D}$ thresholding to remove $5 \%$ of the pixel values consequently removing background features. The cell of interest was then examined for movement by using the phase data as a reference in the lateral and axial dimension. This advancement in technology has allowed a better understanding of the physical process of invasion of the epithelial cell through the BMEC layer, showing the changes of cell shape.

Data were collected from seven experiments totalling 38 cells, which were scored by two independent investigators regarding the position of each cell over time. Table 1 shows the scoring regime that was adopted to identify the level of invasion through the endothelial layer in stages. We found that $80 \%$ of the PC3-GFP cells had bound within $60 \mathrm{~min}$ and $100 \%$ of the cells had bound to the endothelial layer within $90 \mathrm{~min}$. Within $136 \mathrm{~min}, 65 \%$ of these cells had penetrated to a position half way between the upper and lower surface of the endothelium, while $68 \%$ had contact with the coverslip by $170 \mathrm{~min}$. At this point, many of the cells remained static and did not proceed further. However, $29 \%$ of the total population did achieve complete invasion through the layer after $232 \pm 43 \mathrm{~min}$

\section{Stimuli of prostate epithelial cells invasion}

Previously, we have shown that the PC-3 cells could be stimulated to invade through the synthetic basement membrane, Matrigel, in response to stimuli from indirect coculture with both primary BME and BMS cells. Therefore, we determined the potential of BMECs and BMS to stimulate PC-3 invasion and determined the utility of this assay to evaluate the invasive responses of primary prostate epithelial cells to different stimuli.

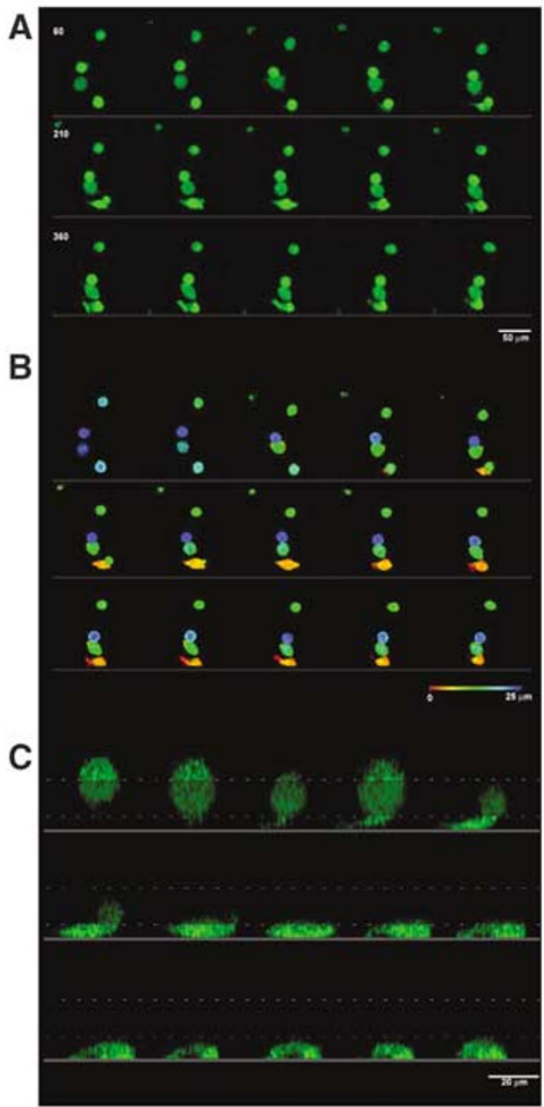

D

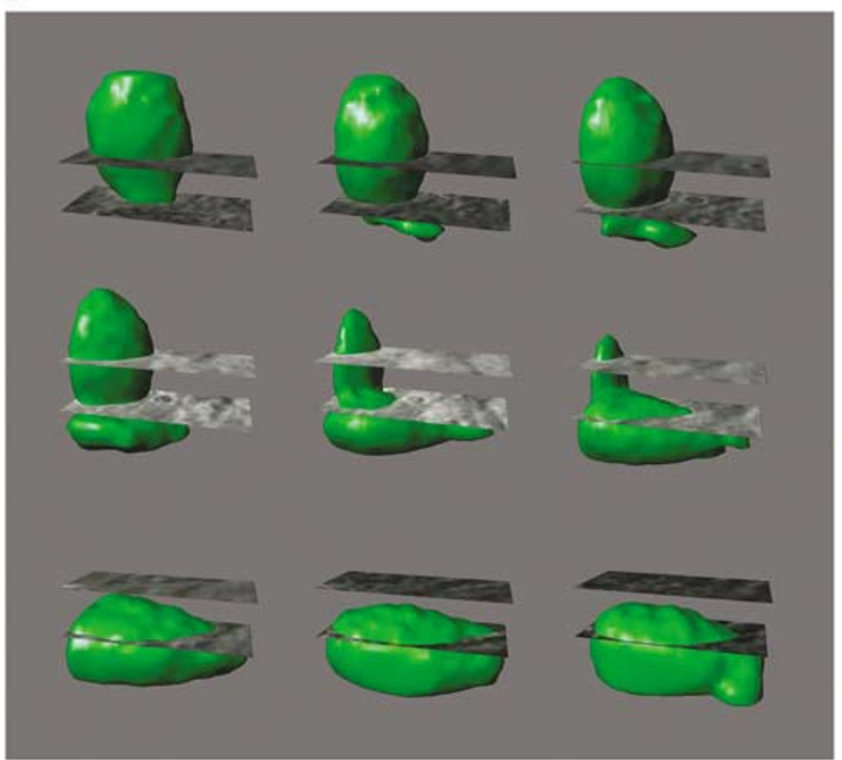

Figure 2 (A) Confocal time-lapse of PC3-GFP cells interacting with the BMEC cell layer over 30 min increments (unprocessed volume). (B) Height coded 3D image showing the height each cell is positioned at each time point (red indicates the bottom of the endothelial layer, blue the top). (C) 3D axial projection of the bottom most cell in the previous images, the dashed line indicates the volume taken by the endothelial layer but does not account for endothelial junctions. (D) Four-dimensional isosurface reconstruction of this cell showing changes in cell volume during invasion.

The invasion chamber model, shown in Figure 3A, utilises an $8 \mu \mathrm{M}$ pore invasion chamber precoated with Matrigel suspended above the stimuli of choice. To eliminate any stimulatory effects of 
A

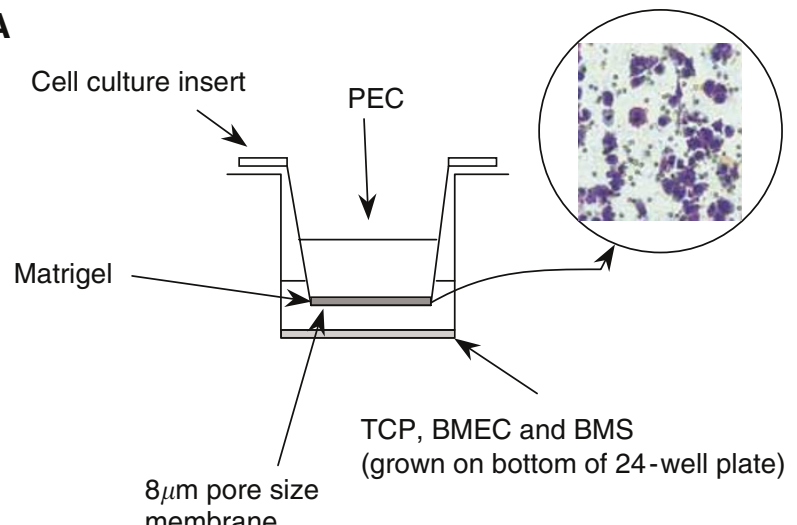

membrane

\section{B}
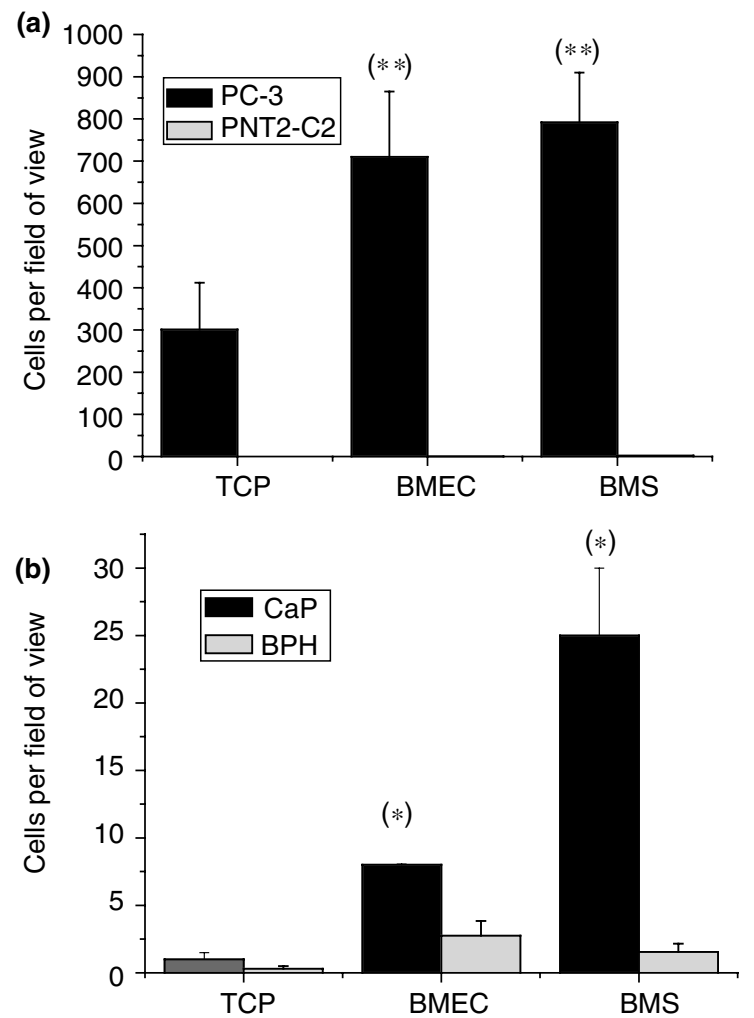

Figure 3 (A) Matrigel invasion chamber model seeded with $1 \times 10^{5}$ prostate epithelial cells. Prostate epithelial cell were fixed and stained in $2 \%$ crystal violet. Typical field of view of stained cells shown. (B) (a) Number of PC-3 and PNT2-C2 cells that invaded through Matrigel towards either TCP, BMEC or BMS $(n=3)$. (b) Number of primary cultured prostate cells from patients with $\mathrm{CaP}(n=7)$ or $\mathrm{BPH}(n=8)$ that invaded through Matrigel towards either TCP, BMEC or BMS. (*) Denotes significant difference; $P<0.05$. (**) Denotes significant difference to TCP stimulated $P C-3 ; P<0.05$

different culture medium, all assays were conducted in the presence of DMEM/0.1\% BSA, which did not effect cell viability during the course of the assay. The number of cells that invaded through the Matrigel in response to each stimulus is shown in Figure 3B. The normal prostate epithelial cell line PNT2-C2 was not stimulated to invade through Matrigel by BMECs or by BMS. However, both BMECs and BMS induced PC- 3 to invade $(P=0.033$ and 0.039 , respectively as compared to TCP control) to a similar degree $(P=0.69)$.
Replacing the prostate epithelial cell lines with primary prostate epithelial cells showed that both BMECs and BMS induce malignant prostate epithelial cells to invade $(P=0.0003$ and 0.0009 , respectively compared to control). Unlike the cell line model, BMS had a three-fold greater stimulatory effect on malignant primary prostate epithelial cells than the BMECs $(P=0.0093)$. Both BMECs and BMS did not significantly induce primary epithelial cells isolated from benign prostates to invade through Matrigel ( $P=0.07$ and 0.221 , respectively).

\section{Prostate epithelial invasion in the modelled bone marrow environment}

To increase the complexity of the invasion model to mirror the in vivo bone marrow microenvironment more closely, cell culture inserts $(8 \mu \mathrm{m})$ were coated with Matrigel and BMEC cells were grown as a monolayer over the top of the formed Matrigel basement membrane. These inserts were placed in a well of a 24-well plate containing either TCP or BMS (Figure 4A). As some endothelial cells migrate through to the base of the insert, we had to be sure that we would be able to distinguish between the endothelial and epithelial cells. Instead of standard crystal violet to stain all cells, we selectively stained for epithelial cells with an anti-pan cytokeratin antibody and counterstained with haematoxylin.

The presence of an endothelial barrier does not prevent invasion of PC-3 cells towards BMS (Figure $4 \mathrm{~B}(\mathrm{a})$ ); however, there is a marked increase in the number of PC-3 cell invading towards TCP with significantly similar numbers invading towards both TCP and BMS stimuli ( $136 \pm 32$ and $107 \pm 9 ; P=0.498)$. This is also observed with the malignant primary prostate epithelial cells; however, the numbers of invasive cells were low $(5 \pm 1.9$ and $6 \pm 2.2$ towards TCP and BMS, respectively; $P=0.802$ ). Addition of prostate epithelial cells induced migration of BMECs through Matrigel in the presence of TCP $(100 \pm 30$ for PC-3 and $78 \pm 35$ for PNT2-C2; $P=0.0117$ and 0.065 , respectively). The addition of a BMS stimulus induced an overall increase in BMEC invasion with or without prostate epithelial cells. Only PNT2-C2 induced significantly more BMEC invasion than the no prostate epithelial cell control $(355 \pm 35$ vs $162 \pm 30 ; P=0.00751)$. Primary prostate epithelial cells had a weaker effect on the BMECs, inducing fewer endothelial cells to invade towards TCP, with only $\mathrm{BPH}$ cells stimulating significantly more endothelial cells to invade $(73 \pm 8$ vs $34 \pm 11$; $P=0.037)$ than the no prostate epithelial cells control. Unlike the prostate epithelial cell line response, both benign and malignant primary prostate epithelial cells did not induce significantly more endothelial invasion in the presence of a BMS stimulus than the no prostate epithelial cells control $(P=0.8233$ and 0.2208 for $\mathrm{CaP}$ and $\mathrm{BPH}$, respectively).

\section{Inhibition of CXCR4 signalling by T140}

The utility of these invasion models to analyse the role of specific stimulators and inhibitors of prostate epithelial cells was assessed. It has been shown that SDF-1, expressed by both BMS and BMECs (Aiuti et al, 1997), and its receptor CXCR4 play an important role in targeting not just blood cells but also prostate epithelial cells towards the BMS (Taichman et al, 2002; Sun et al, 2003). Therefore, we examined the ability of SDF-1, and its specific peptide inhibitor T140, to stimulate invasion of prostate epithelial cells in our models.

Immunohistochemical analysis of prostate sections taken from patients with benign disease, localised $\mathrm{CaP}$ or bone metastases (Figure 5A) showed that both BPH and localised CaP expressed high levels of CXCR4 within the nucleus. Prostate bone metastases, by contrast, express high levels of CXCR4 in both the nucleus and the cytoplasm. FACs analysis of PC-3 and PNT2-C2 cell lines and primary benign and malignant prostate epithelial cells (Figure 
A

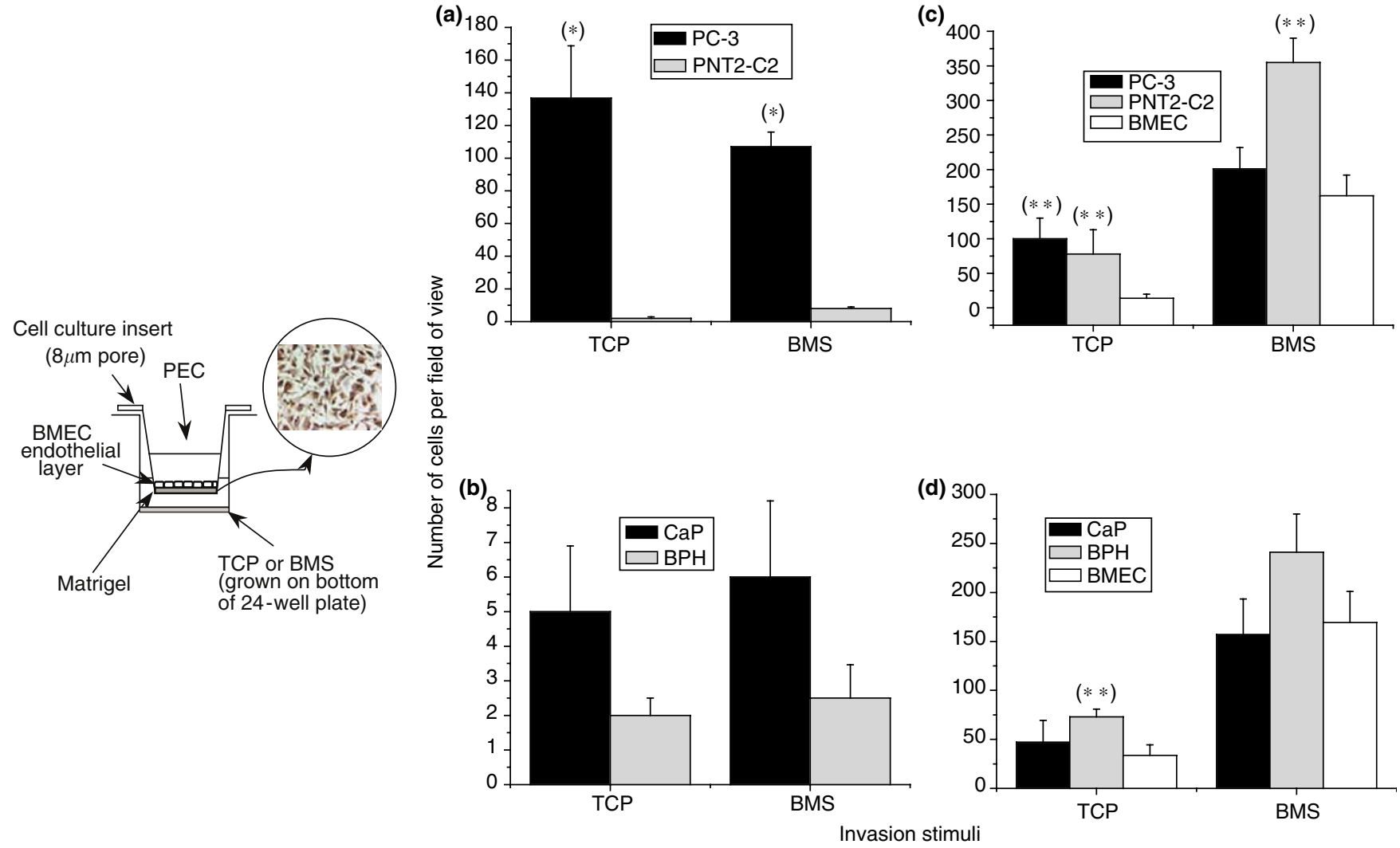

B
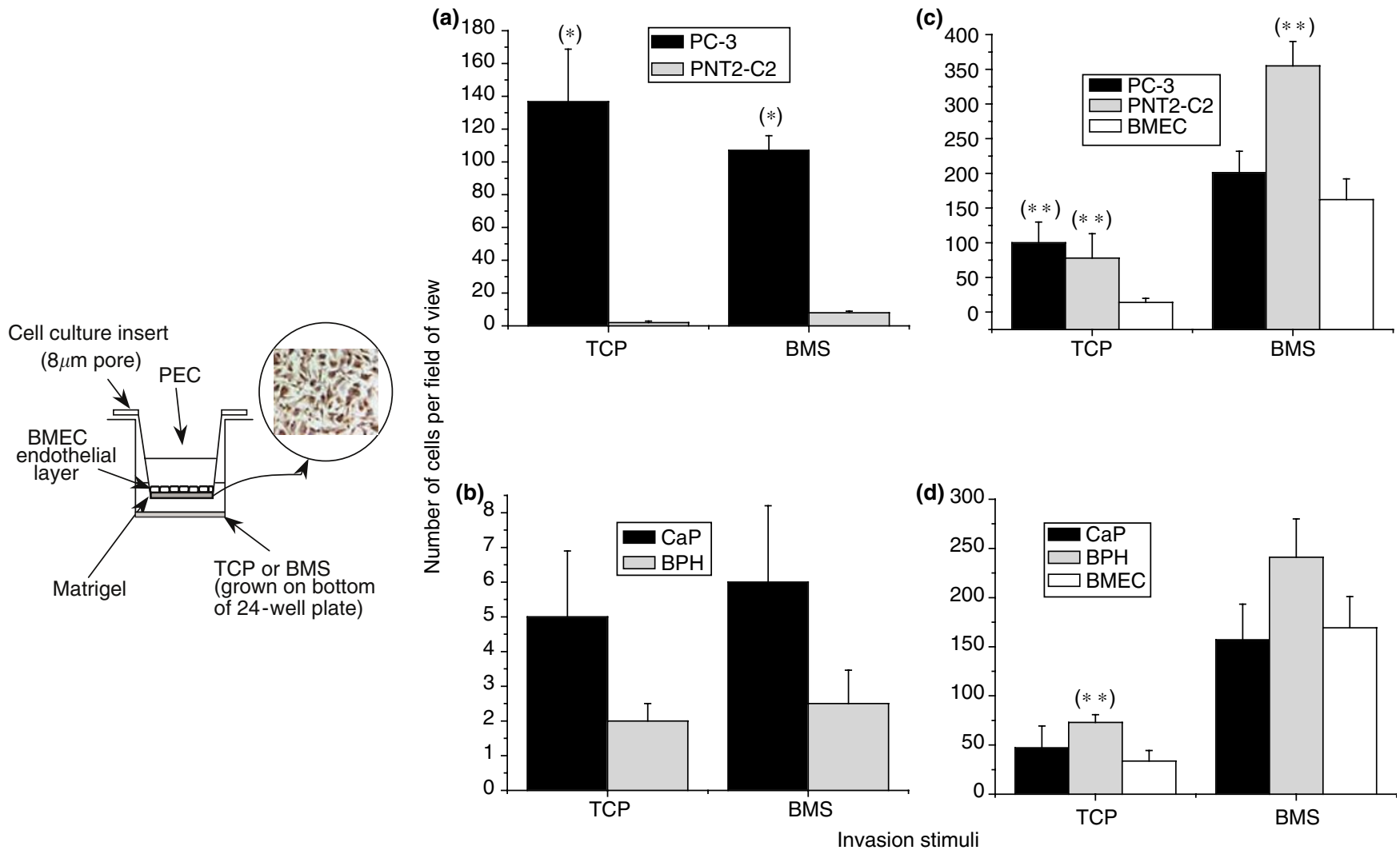

(c)

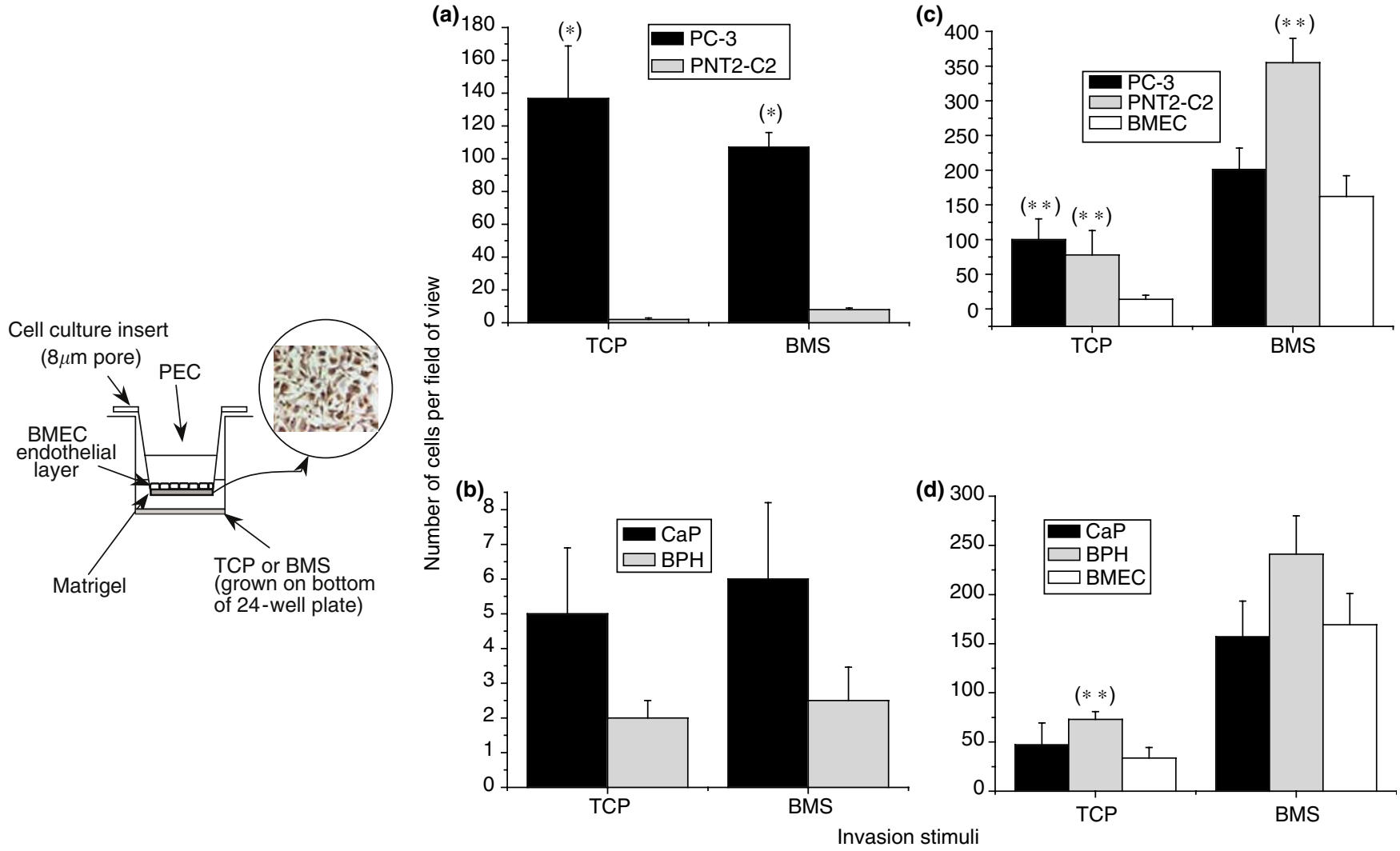

Figure 4 (A) Bone marrow endothelium invasion chamber model seeded with $\mathrm{I} \times 10^{5}$ prostate epithelial cells. Prostate epithelial cells fixed in methanol/ acetone, stained for cytokeratin by immunohistochemistry and counterstained with haematoxylin. Typical field of view of stained cells shown. (B) Number of (a) PC-3 $(n=5)$, PNT2-C2 $(n=3),(b) \mathrm{CaP}(n=6)$ and BPH $(n=5)$ epithelial cells that invaded through Matrigel and an endothelial barrier towards either TCP or BMS. (*) Denotes significant difference $P<0.05$. The number of BMEC cells that invaded through the Matrigel either on their own or in the presence of prostate epithelial cell lines (c) or primary prostate epithelial cells (d) in response to TCP or BMS. (***) Denotes significant difference to the no epithelial control, $P<0.05$.

$5 \mathrm{~B}(\mathrm{~b}))$ shows that similar percentages of $\mathrm{PC}-3, \mathrm{BPH}$ and $\mathrm{CaP}$ epithelial cells express CXCR4 $(P>0.05)$ but expression was lower in PNT2-C2 cells (23\% reduction; $P=0.0048$ as compared to $\mathrm{CaP}$ ). However, there was considerable and significant variation $(P<0.05)$ in the levels of CXCR4 expression between primary and cell lines and in relation to their type. PC-3 cells expressed the highest levels of CXCR4 followed by primary $\mathrm{CaP}$ and $\mathrm{BPH}$ prostate epithelial cells (geometric mean fluorescence of $115.8 \pm 10.7,71 \pm 5.8$ and $51 \pm 4.8$, respectively). The lowest level of expression was seen in the transformed normal prostate epithelial cell line PNT2-C2 with a geometric mean fluorescence of $29 \pm 6.7$.

The effect of the specific CXCR4 inhibitor, T140 (Tamamura et al, 2001, 2003), on prostate epithelial cell invasion was then assessed in the Matrigel invasion model with the PC-3 cell line (Figure 6). The invasive stimulatory effect of the maximal invasive dose of SDF-1, $15 \mathrm{ng} \mathrm{ml}^{-1}$ (titration data not shown), was compared to the invasive stimuli from BMECs and primary BMS with or without $10 \mu \mathrm{g} \mathrm{ml}^{-1} \mathrm{~T} 140$ (concentration required to inhibit completely SDF-1 signalling in prostate epithelial cells (titration data not shown)). Bone marrow endothelial cell lines and BMS both induced PC-3 invasion across the Matrigel barrier, as did $15 \mathrm{ng} \mathrm{ml}^{-1}$ SDF-1, although SDF-1 induced significantly less PC-3 invasion than either the BMECs $(141 \pm 12$ vs $490 \pm 36 P=0.0007)$ or the BMS $(141 \pm 12$ vs $503 \pm 29 P=0.0004)$. Addition of $10 \mu \mathrm{M}$ T140 resulted in a complete block in invasion towards SDF-1 $(P=0.0103)$. However, unlike SDF-1-induced invasion, T140 only reduced the levels of PC-3 invasion incompletely (29\% towards $\operatorname{BMEC}(P=0.011)$ and by $59 \%$ towards BMS $(P=0.001))$.

\section{DISCUSSION}

We have previously developed models allowing the study of the interactions between malignant prostate epithelial cells and endothelial or BMS layers (Lang et al, 1997, 1998; Scott et al, 2001). We have developed these models to target the blood/BMS endothelial barrier specifically, thereby allowing the visualisation not just of the sites of binding but also of the prostate epithelial invasive process. The development of such models enables the characterisation and comprehension of the mechanisms of metastasis in prostate and other cancers to be carried to a greater depth. Understanding and modelling this process will not only elucidate new therapeutic targets but also may help to elaborate their mode of action. In addition, it will help to explore the potential therapeutic benefit of novel chemotherapeutic agents such as T140 (Tamamura et al, 2001).

We have shown that prostate epithelial cells bind preferentially to primary human bone marrow endothelial cells and that only malignant prostate epithelial cells can invade through a matrigel basement membrane (Scott et al, 2001). With a view to creating robust models of epithelial/endothelial interactions, we have replaced the primary BME cells with the BMEC cell line. This line displays characteristics indistinguishable from human primary 


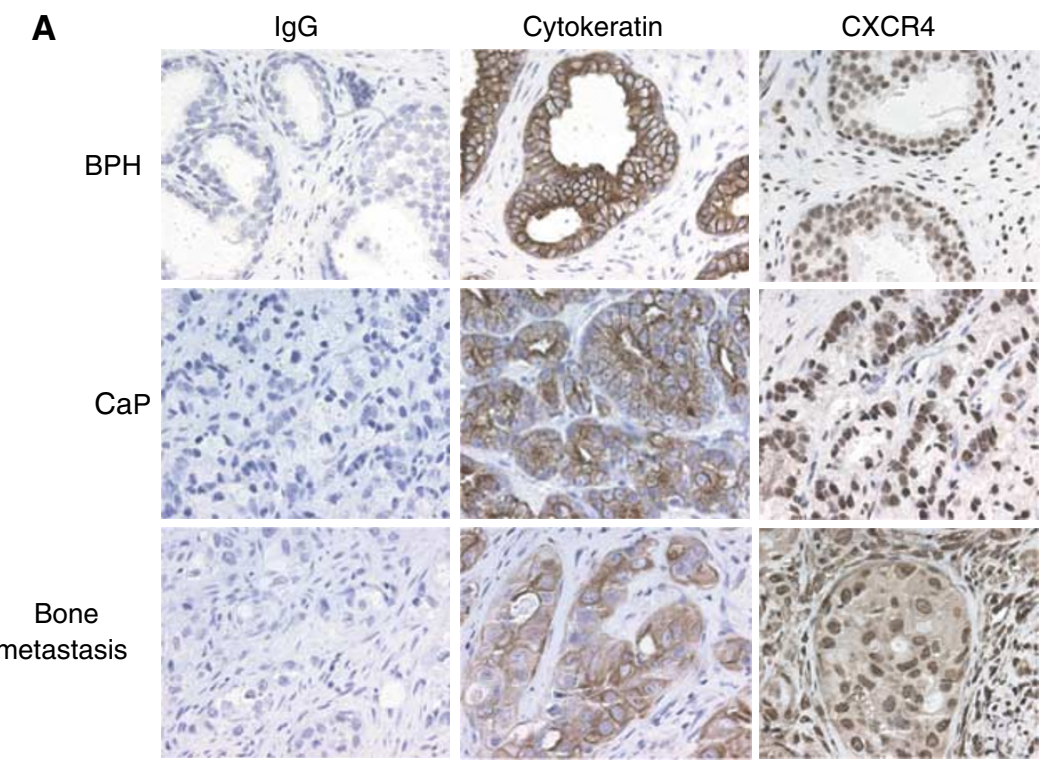

\section{B}

(a)
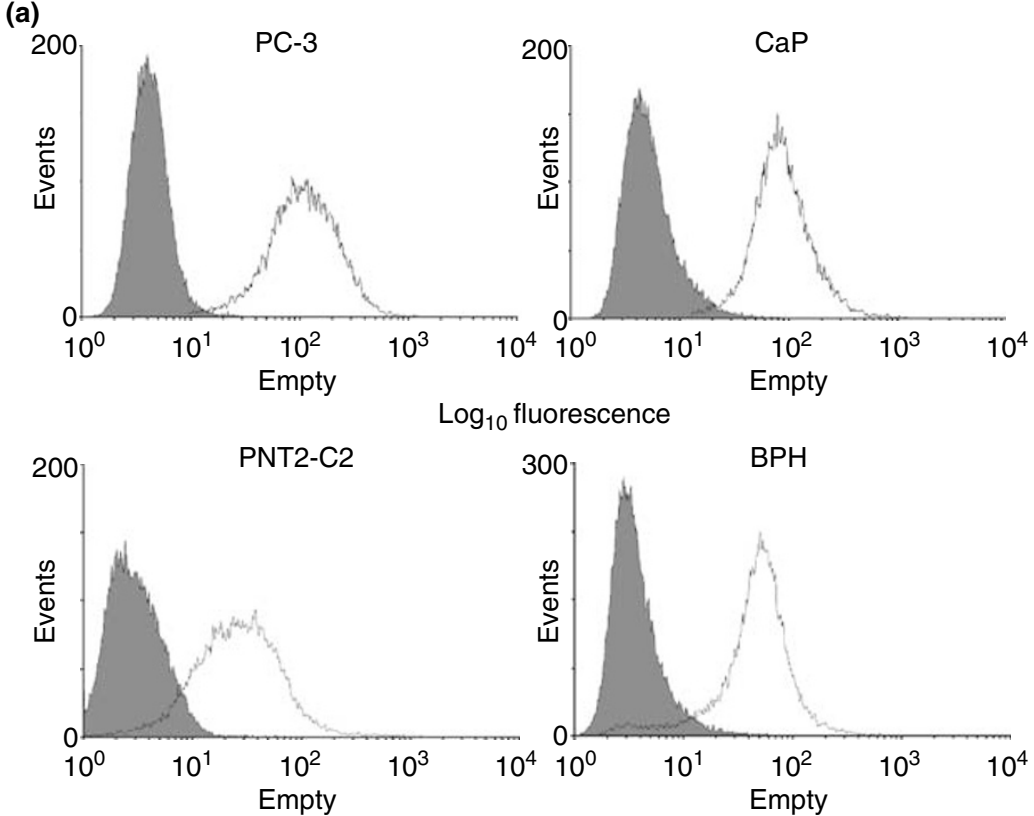

$\log _{10}$ fluorescence

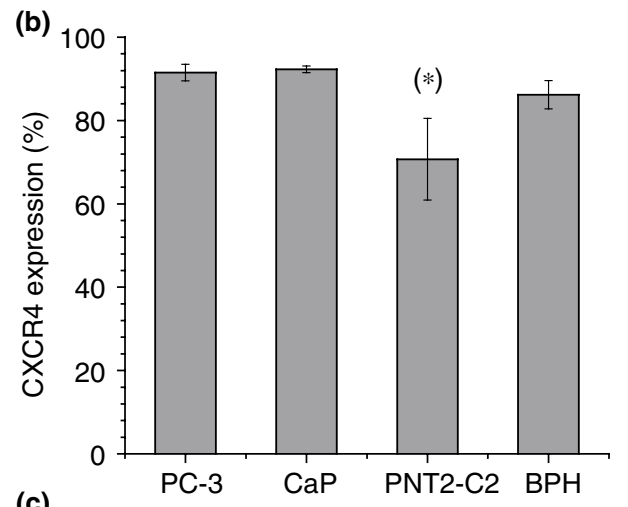

(c)

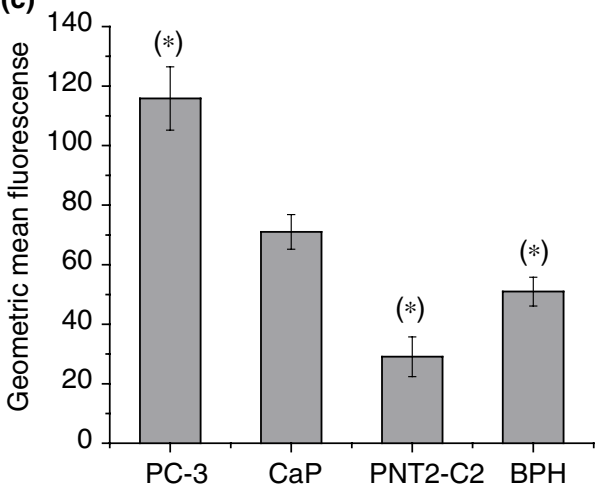

Figure 5 (A) Immunohistochemical staining of prostate sections taken from patients with $\mathrm{BPH}$, CaP or bone metastases. These sections were labelled with IgGI, anti-pan-cytokeratin and anti CXCR4 (clone I2G5) and stained with DAB (brown). These sections were counterstained using haematoxylin (blue). (B) FACs CXCR4 receptor expression in primary cultured prostate from patients with $\mathrm{CaP}(n=6)$ or BPH $(n=5)$ and on the PC-3 and PNT2-C2 prostate cell lines $(n=3)$. (a) Histograms showing expression of CXCR4 by each cell culture as compared to lgG control (shaded histogram). (b) Percentage of cells expressing the CXCR4 receptor; (*) denotes significant difference to CXCR4 expression in patients with CaP; $P<0.05$. (c) Level of expression of CXCR4 by each prostate epithelial population; (*) denotes significant difference to CaP, $P<0.05$.

BME cultures (Almeida-Porada and Ascensao, 1996). We have also utilised an GFP-expressing invasive prostate epithelial cell line, PC3-GFP (Sharrard and Maitland, 2000), to allow visualisation and measurement of the process of cellular trans-migration by confocal microscopy.

Our results show that the prostate epithelial cells bind rapidly to the BMEC cell layer. This process is complete within $90 \mathrm{~min}$, confirming the findings in previous clinical studies whereby prostate cells released into the circulation during surgery were removed from the peripheral blood within $2 \mathrm{~h}$ (McIntyre et al, 2002). Our results show that the location of the binding is very specific, with all the PC3-GFP cells binding at endothelial cell junctions. It has been shown that prostate epithelial cells interact directly with the BME cells, initially via selectins and this interaction is then stabilised by integrin binding (Orr et al, 2000). These are not the only binding steps, since antibodies to 
510

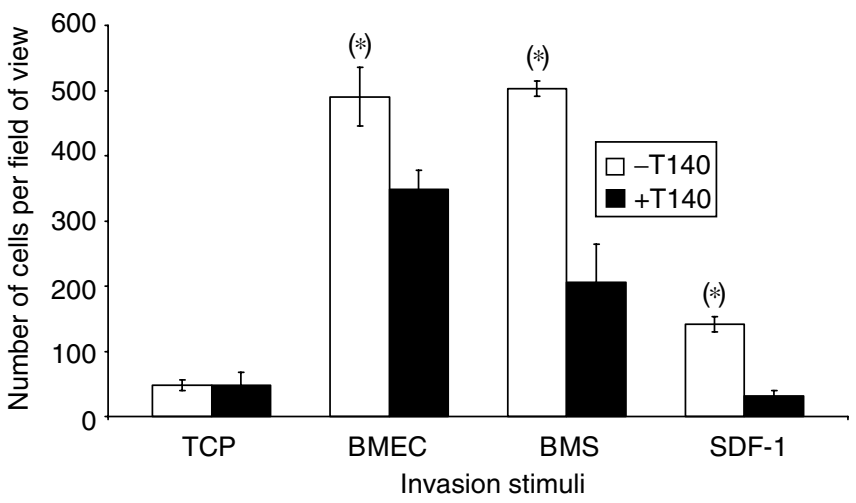

Figure 6 PC-3 invasion through Matrigel towards TCP, BMEC, BMS and SDF-I $\left(15 \mathrm{ng} \mathrm{ml}^{-1}\right)$ with or without the CXCR4 receptor blocked with the CXCR4-specific TI40 ( $n=3)$. (*) Denotes significant difference $P<0.05$.

CD11a, CD18, LFA-1 and CD31 have also been shown to interfere with the binding process (Lehr and Pienta, 1998).

Once bound, prostate epithelial cells induce endothelial cell retraction. The precise mechanism of this process, which is an essential component of cellular trans-migration, is at present unclear. A major component of the signalling cascade modulating endothelial permeability is the intracellular level of $\mathrm{Ca}^{2+}$ (Curry, 1992). Studies by Lewalle et al (1998) demonstrated that the binding of breast epithelial cells to HUVECs induced a transitory rise in HUVEC intracellular concentration of $\mathrm{Ca}^{2+}$ resulting in endothelial retraction and epithelial migration. This rise in $\mathrm{Ca}^{2+}$ levels and retraction of the endothelial layer is entirely dependent on cell-to-cell contact and inhibiting this rise in intracellular $\mathrm{Ca}^{2+}$ concentration inhibited breast epithelial trans-endothelial migration. The binding of prostate epithelial cells and melanoma cells also have induced raised intracellular $\mathrm{Ca}^{2+}$ levels (Pili et al, 1993), which correlated with increased binding of the epithelial cells. Previous studies by our group (Montague et al, 2004) have shown that treatment of BMEC with the bisphosphonate zoledronic acid, a potent calcium chelating agent and blocker of the mevalonate transduction pathway, tightens the endothelial-to-endothelial cell binding in the absence of prostate epithelial cells. It is also a potent inhibitor of prostate epithelial trans-endothelial migration. However, the tightening of the endothelial-to-endothelial cell bonding is not observed with high doses $(100 \mu \mathrm{M})$ of the weaker bisphosphonate pamidronate, or with EDTA, both of which are potent $\mathrm{Ca}^{2+}$ chelating agents. Therefore, it is unlikely that endothelial retraction relates to decreased levels of extracellular $\mathrm{Ca}^{2+}$ although the effects on intracellular $\mathrm{Ca}^{2+}$ levels at the higher concentrations observed in relation to endothelial binding experiments are unknown (Montague et al, 2004).

The effect of agents such as zoledronic acid in reducing the ability of PC-3 cells to invade across endothelial barriers towards BMS suggest that a major component affecting migration is inhibition of transduction pathways related to the Rho axis. Zoledronic acid is an effective inhibitor of the mevalonate pathway, which is known to be related to the Rho pathway through Ras linkage (Virtanen et al, 2002). Inhibition of this pathway affects downstream prenylation of small GTPases such as Rho, which is known to be involved integrally in cell motility. Therefore, an early event following integrin $\beta 1$-binding may be the induction of a specific pathway or pathways, which relate to Rho. Whether or not this is a consequence of flux in intracellular calcium levels within endothelial cells remains to be determined. The role of integin $\beta 1$ and the interaction between the prostate epithelial cell and the endothelial tight cell junction in relation to induced rises in intracellular $\mathrm{Ca}^{2+}$ concentrations is certainly worthy of further study.
Malignant prostate cells migrate across the endothelial barrier in a manner similar to melanoma cells (Voura et al, 1998). The prostate epithelial cells bind rapidly to the endothelial junctions, where they begin to penetrate the endothelial barrier. The prostate epithelial cells show marked membrane blebbing and lamellipodial formation on the lower surface of the cell (Figure 1) at the point of contact between the two cells. The prostate epithelial cell then generates a pseudopodial extension, which penetrates the endothelial cell layer, the endothelial cells retract and the prostate cell moves through the endothelial barrier. As with the migration across endothelia observed in melanoma cells, prostate epithelial trans-migration is considerably slower than leukocyte transmigration, with $29 \%$ of cells completing the transit within $4 \mathrm{~h}$. This extravasation time is comparable to that observed for melanoma cells (Voura et al, 1998), rat ascites hepatoma cells (Ohigashi et al, 1989) and other tumour cells (Kramer and Nicolson, 1979). However, it has been shown that over $50 \%$ of monocytes can cross an endothelium within the first hour of contact (Sandig et al, 1997) without inducing endothelial cell retraction. This difference may be due to the fact that epithelial cells are larger than monocytes and therefore require retraction of the endothelium, thereby resulting in the significantly increased time of invasion.

Figure $4 \mathrm{~B}$ shows that the addition of a BMEC barrier does not inhibit PC-3 invasion but appears to act as a stimulus in the TCP control. As shown in Figure 3, both BMS and BMECs are powerful invasion stimuli, possibly inducing maximal invasion within our assay system. This would explain why we do not observe an enhanced effect in the combined BMEC BMS assay model. We have also shown that trans-endothelial migration by prostate epithelial cells induces the invasion of bone marrow endothelial cells across the Matrigel basement membrane. The exact nature of this basement membrane invasion by the bone marrow endothelial cells is unknown but may be a result of the weakening of the basement membrane itself due to prostate epithelial proteolytic secretions, a phenomenon known to occur during prostate epithelial migration and metastasis (Hart et al, 2002). However, Figure $4 \mathrm{~B}$ shows that in the presence of both PNT2-C2 and BPH there is significant BMEC invasion without epithelial invasion, which suggests that the overall integrity of the basement membrane has remained intact. Figure $4 \mathrm{~B}$ also shows a marked increase in endothelial cell invasion in the presence of BMS suggesting that the BMECs may be responding to factors other than the potential breakdown of the basement membrane by the prostate epithelial cell, for example, VEGF or other angiogenic factors.

Taichman et al (2002) showed that prostate epithelial cells bind to both osteosarcoma cell lines, MG-63 and SaOS-2, and to human bone marrow endothelial cells. Previously, we have shown that both benign and malignant primary prostate epithelial cells bind preferentially to BMS (Lang et al, 1997, 1998) and to BME cells to a similar degree (Scott et al, 2001) and that prostate epithelial cells shed intraoperatively into the peripheral blood during transurethral resection of the prostate are undetectable within $2 \mathrm{~h}$ of the end of the operation (McIntyre et al, 2002). Since both benign and malignant prostate epithelial cells express CXCR4 and bind preferentially to BME cells, a process which is enhanced by SDF-1 signalling, it is highly likely that prostate epithelial cells that are released into the circulation, whether benign or malignant, are rapidly removed from the blood by binding to the bone marrow endothelium and possibly to endothelial surfaces in other capillary beds.

The chemokine receptor, CXCR4, and its endogenous ligand SDF-1 have been shown to be key components in both chemokineinduced leucocyte trafficking (Aiuti et al, 1997, 1999; Hamada et al, 1998 ) and the migration of malignant epithelial cells to the BMS (Koshiba et al, 2000; Muller et al, 2001; Robledo et al, 2001; Murakami et al, 2002; Schrader et al, 2002; Taichman et al, 2002; 
Burger et al, 2003; Sun et al, 2003). This has led to the hypothesis that CXCR4 is the key component of metastatic implantation in bone marrow and that it represents an important therapeutic target for metastatic bone disease. Blockade of the CXCR4 signalling in malignant breast epithelial cells either by neutralising antibodies (Muller et al, 2001) or by peptide antagonists such as T140 (Tamamura et al, 2003) has been shown to inhibit metastasis in vivo.

Utilising our in vitro assays of metastasis, we sought to determine the influence of SDF-1 signalling via CXCR4 as a stimulus for invasion toward BMS. The analysis of CXCR4 expression by metastatic and benign cell lines, primary prostate epithelial cells and tissue sections of $\mathrm{BPH}$, primary cancer and bone metastases demonstrate that all prostate epithelial cells express CXCR4, although the levels and localisation of expression vary according to the type of disease affecting the cell. Our results correlate with the observation of Spano et al (2004) that CXCR4positive nuclear staining of non-small-cell lung cancer correlates with a significantly better outcome. Both $\mathrm{BPH}$ and localised $\mathrm{CaP}$ sections show strong CXCR4 nuclear staining while the prostate bone metastases, a poor prognostic indicator, showed strong CXCR4 nuclear and cytoplasmic staining. Our results also confirm the observation of Sun et al (2003) that the level of CXCR4 expression increased with increasing malignancy, with the greatest expression being observed in the aggressively metastatic cell line PC-3 and in the human bone metastasis sections. This increasing expression suggests that CXCR4/SDF-1 signalling may be one of the key signalling pathways for metastatic spread to the bone. The importance of this pathway was demonstrated by Taichman et al (2002), utilising a matrigel basement membrane invasion assay to show that SDF-1 signalling induced both DU145 and PC3 cells to invade. However, this study only utilised recombinant SDF-1 and anti-CXCR4 antibody inhibitors and therefore did not determine whether SDF-1/CXCR4 signalling pathway was the sole chemo-attractant in the spread of prostate epithelial

\section{REFERENCES}

Aiuti A, Tavian M, Cipponi A, Ficara F, Zappone E, Hoxie J, Peault B, Bordignon C (1999) Expression of CXCR4, the receptor for stromal cellderived factor-1 on fetal and adult human lympho-hematopoietic progenitors. Eur J Immunol 29: 1823-1831

Aiuti A, Webb IJ, Bleul C, Springer T, Gutierrez-Ramos JC (1997) The chemokine SDF-1 is a chemoattractant for human CD34+ hematopoietic progenitor cells and provides a new mechanism to explain the mobilization of CD34+ progenitors to peripheral blood. J Exp Med 185: $111-120$

Almeida-Porada G, Ascensao JL (1996) Isolation, characterization, and biologic features of bone marrow endothelial cells. J Lab Clin Med 128: $399-407$

Berthon P, Cussenot Hopwood L, Le Duc A, Maitland N (1995) Functional expression of SV40 in normal prostatic epithelial and fibroblastic cells: differentiation pattern of non-tumourigenic cell lines. Int J Oncol 6: $333-343$

Bertolini F, Dell'Agnola C, Mancuso P, Rabascio C, Burlini A, Monestiroli S, Gobbi A, Pruneri G, Martinelli G (2002) CXCR4 neutralization, a novel therapeutic approach for non-Hodgkin's lymphoma. Cancer Res 62: $3106-3112$

Bryden AA, Hoyland JA, Freemont AJ, Clarke NW, Schembri Wismayer D, George NJ (2002) E-cadherin and beta-catenin are down-regulated in prostatic bone metastases. Br J Urol Int 89: 400-403

Burger M, Glodek A, Hartmann T, Schmitt-Graff A, Silberstein LE, Fujii N, Kipps TJ, Burger JA (2003) Functional expression of CXCR4 (CD184) on small-cell lung cancer cells mediates migration, integrin activation, and adhesion to stromal cells. Oncogene 22: 8093-8101

Coutinho LH, Gilleece MH, de Wynter E, Will A, Testa NG (1993) Clonal and long-term cultures using human bone marrow. In Haemopoiesis: A Practical Approach Testa NG, Molineux G (eds) pp 75-106. Oxford: Oxford University Press cells to the bone. Our study confirms that SDF-1 is a potent stimulus for invasion but the level of that invasion is significantly less than that seen by using either BMEC cells and/or BMS alone. This measured phenomenon is reinforced by the observation that use of a specific CXCR4 antagonist peptide (T140), at a concentration which blocks prostate epithelial cell invasion in response to maximum levels of SDF-1 signalling, does not block invasion towards either BMEC or BMS completely. Thus, it is confirmed that while the CXCR4/SDF-1 signalling pathway is important in prostate epithelial metastasis, it is not the only signalling pathway involved. This study of CXCR4/SDF-1 signalling in $\mathrm{CaP}$ metastasis to the bone marrow demonstrates the need for more integrated models of bone metastasis. The BMS is a highly complex environment supporting haematopoiesis and as such produces a wide variety of chemokines, which may attract metastatic epithelial cells. While basic models may identify individual 'key' components in metastatic disease, it is necessary to utilise more complex, coculture models to determine the exact nature of each signalling pathway within the complex bone marrow environment.

We have shown that it is possible to generate in vitro models that are able to mimic the highly complex bone metastatic environment. These models show that epithelial-endothelial binding occurs rapidly and that trans-endothelial migration is initiated at the intercellular joints between multiple endothelial cells. This results in endothelial cell retraction and epithelial invasion within $4 \mathrm{~h}$. We have also shown that while CXCR4/SDF-1 signalling is an important stimulus for epithelial invasion towards the bone marrow, it is not the only stimulus emanating from the bone marrow attracting metastatic prostate epithelial cells.

The main advantage of such models over the standard mono culture/stimuli variations of Bowden invasion chambers are that they allow the study of proposed components of the metastatic process and the effect of novel chemotherapeutic agents within the relevant background of chemokines and growth factors.

Curry FE (1992) Modulation of venular microvessel permeability by calcium influx into endothelial cells. FASEB J 6: 2456-2466

Hamada T, Mohle R, Hesselgesser J, Hoxie J, Nachman RL, Moore MA, Rafii S (1998) Transendothelial migration of megakaryocytes in response to stromal cell-derived factor 1 (SDF-1) enhances platelet formation. $J$ Exp Med 188: 539-548

Hart CA, Scott LJ, Bagley S, Bryden AA, Clarke NW, Lang SH (2002) Role of proteolytic enzymes in human prostate bone metastasis formation: in vivo and in vitro studies. Br J Cancer 86: $1136-1142$

Hood JD, Cheresh DA (2002) Role of integrins in cell invasion and migration. Nat Rev Cancer 2: $91-100$

Kaighn ME, Narayan KS, Ohnuki Y, Lechner JF, Jones LW (1979) Establishment and characterization of a human prostatic carcinoma cell line (PC-3). Invest Urol 17: 16-23

Koshiba T, Hosotani R, Miyamoto Y, Ida J, Tsuji S, Nakajima S, Kawaguchi M, Kobayashi H, Doi R, Hori T, Fujii N, Imamura M (2000) Expression of stromal cell-derived factor 1 and CXCR4 ligand receptor system in pancreatic cancer: a possible role for tumor progression. Clin Cancer Res 6: $3530-3535$

Kramer RH, Nicolson GL (1979) Interactions of tumor cells with vascular endothelial cell monolayers: a model for metastatic invasion. Proc Natl Acad Sci USA 76: 5704-5708

Lang SH, Clarke NW, George NJ, Allen TD, Testa NG (1998) Interaction of prostate epithelial cells from benign and malignant tumor tissue with bone-marrow stroma. Prostate 34: 203-213

Lang SH, Clarke NW, George NJ, Testa NG (1997) Primary prostatic epithelial cell binding to human bone marrow stroma and the role of alpha2beta1 integrin. Clin Exp Metastasis 15: 218-227

Lehr JE, Pienta KJ (1998) Preferential adhesion of prostate cancer cells to a human bone marrow endothelial cell line. J Natl Cancer Inst 90: $118-123$ 
Lewalle JM, Cataldo D, Baiou K, Lmabert CA, Foidart JM (1998) Endothelia cell intracellular $\mathrm{Ca}^{2+}$ concentration is increased upon breast tumor cell contact and mediates tumor cell transendothelial migration. Clin Exp Metastasis 16(1): $21-29$

McIntyre IG, Bhatt RI, Clarke NW (2002) Isolation of epithelial cells from blood and bone marrow of prostate cancer patients. Prostate Cancer Prostate Dis 5: S21

McIntyre IG, Spreckley K, Clarke RB, Anderson E, Clarke NW, George NJ (2000) Optimization of the reverse transcriptase polymerase chain reaction for the detection of circulating prostate cells. $\mathrm{Br} J$ Cancer 83: 992- 997

Meye A, Bilkenroth U, Schmidt U, Fussel S, Robel K, Melchior AM, Blumke K, Pinkert D, Bartel F, Linne C, Taubert H, Wirth MP (2002) Isolation and enrichment of urologic tumor cells in blood samples by a semiautomated CD45 depletion autoMACS protocol. Int J Oncol 21: 521 - 530

Montague R, Hart CA, George NJ, Ramani VAC, Brown MD, Clarke NW (2004) Differential inhibition of invasion and proliferation by bisphosphonates: anti metastatic potential of zoledronic acid in prostate cancer. Eur Urol 46: 389 - 402

Muller A, Homey B, Soto H, Ge N, Catron D, Buchanan ME, McClanahan T, Murphy E, Yuan W, Wagner SN, Barrera JL, Mohar A, Verastegui E, Zlotnik A (2001) Involvement of chemokine receptors in breast cancer metastasis. Nature 410: $50-56$

Murakami T, Maki W, Cardones AR, Fang H, Tun Kyi A, Nestle FO, Hwang ST (2002) Expression of CXC chemokine receptor-4 enhances the pulmonary metastatic potential of murine B16 melanoma cells. Cancer Res 62: $7328-7334$

Ohigashi H, Shinkai K, Mukai M, Ishikawa O, Imaoka S, Iwanaga T, Akedo $\mathrm{H}$ (1989) In vitro invasion of endothelial cell monolayer by rat ascites hepatoma cells. Jpn J Cancer Res 80: 818-821

Orr FW, Wang HH, Lafrenie RM, Scherbarth S, Nance DM (2000) Interactions between cancer cells and the endothelium in metastasis. Pathol 190: $310-329$

Peled A, Petit I, Kollet O, Magid M, Ponomaryov T, Byk T, Nagler A, BenHur H, Many A, Shultz L, Lider O, Alon R, Zipori D, Lapidot T (1999) Dependence of human stem cell engraftment and repopulation of NOD/ SCID mice on CXCR4. Science 283: 845 - 848

Pili R, Corda S, Passaniti A, Ziegelstein RC, Heldman AW, Capogrossi MC (1993) Endothelial cell $\mathrm{Ca}^{2+}$ increases upon tumor cell contact and modulates cell - cell adhesion. J Clin Invest 92: 3017-3022

Ponomaryov T, Peled A, Petit I, Taichman RS, Habler L, Sandbank J, Arenzana-Seisdedos F, Magerus A, Caruz A, Fujii N, Nagler A, Lahav M, Szyper-Kravitz M, Zipori D, Lapidot $T$ (2000) Induction of the chemokine stromal-derived factor-1 following DNA damage improves human stem cell function. J Clin Invest 106: 1331-1339

Robledo MM, Bartolome RA, Longo N, Rodriguez-Frade JM, Mellado M, Longo I, van Muijen GN, Sanchez-Mateos P, Teixido J (2001) Expression of functional chemokine receptors CXCR3 and CXCR4 on human melanoma cells. J Biol Chem 276: $45098-45105$

Sandig M, Negrou E, Rogers KA (1997) Changes in the distribution of LFA1, catenins, and F-actin during transendothelial migration of monocytes in culture. J Cell Sci 110: $2807-2818$
Schrader AJ, Lechner O, Templin M, Dittmar KE, Machtens S, Mengel M, Probst-Kepper M, Franzke A, Wollensak T, Gatzlaff P, Atzpodien J, Buer J, Lauber J (2002) CXCR4/CXCL12 expression and signalling in kidney cancer. Br J Cancer 86: $1250-1256$

Scott LJ, Clarke NW, George NJ, Shanks JH, Testa NG, Lang SH (2001) Interactions of human prostatic epithelial cells with bone marrow endothelium: binding and invasion. Br J Cancer 84: 1417-1423

Sharrard RM, Maitland NJ (2000) Phenotypic effects of overexpression of the MMAC1 gene in prostate epithelial cells. Br J Cancer 83: $1102-1109$

Spano JP, Andre F, Morat L, Sabatier L, Besse B, Combadiere C, Deterre P, Martin A, Azorin J, Valeyre D, Khayat D, Le Chevalier T, Soria JC (2004) Chemokine receptor CXCR4 and early-stage non-small cell lung cancer: pattern of expression and correlation with outcome. Ann Oncol 15: $613-617$

Staller P, Sulitkova J, Lisztwan J, Moch H, Oakeley EJ, Krek W (2003) Chemokine receptor CXCR4 downregulated by von Hippel-Lindau tumour suppressor pVHL. Nature 425: 307-311

Sun YX, Wang J, Shelburne CE, Lopatin DE, Chinnaiyan AM, Rubin MA Pienta KJ, Taichman RS (2003) Expression of CXCR4 and CXCL12 (SDF-1) in human prostate cancers (PCa) in vivo. J Cell Biochem 89: $462-473$

Taichman RS, Cooper C, Keller ET, Pienta KJ, Taichman NS, McCauley LK (2002) Use of the stromal cell-derived factor-1/CXCR4 pathway in prostate cancer metastasis to bone. Cancer Res 62: 1832-1837

Tamamura H, Hori A, Kanzaki N, Hiramatsu K, Mizumoto M, Nakashima H, Yamamoto N, Otaka A, Fujii N (2003) T140 analogs as CXCR4 antagonists identified as anti-metastatic agents in the treatment of breast cancer. FEBS Lett 550: 79-83

Tamamura H, Omagari A, Hiramatsu K, Gotoh K, Kanamoto T, Xu Y, Kodama E, Matsuoka M, Hattori T, Yamamoto N, Nakashima H, Otaka A, Fujii N (2001) Development of specific CXCR4 inhibitors possessing high selectivity indexes as well as complete stability in serum based on an anti-HIV peptide T140. Bioorg Med Chem Lett 11: 1897-1902

Taubert H, Blumke K, Bilkenroth U, Meye A, Kutz A, Bartel F, Lautenschlager C, Ulbrich EJ, Nass N, Holzhausen HJ, Koelbl H, Lebrecht A (2004) Detection of disseminated tumor cells in peripheral blood of patients with breast cancer: correlation to nodal status and occurrence of metastases. Gynecol Oncol 92: 256-261

Thompson IM, Pauler DK, Goodman PJ, Tangen CM, Lucia MS, Parnes HL, Minasian LM, Ford LG, Lippman SM, Crawford ED, Crowley JJ, Coltman Jr CA (2004) Prevalence of prostate cancer among men with a prostate-specific antigen level $<$ or $=4 \mathrm{ng}$ per milliliter. $N$ Engl J Med 350: $2239-2246$

Umbas R, Isaacs WB, Bringuier PP, Xue Y, Debruyne FM, Schalken JA (1997) Relation between aberrant alpha-catenin expression and loss of E-cadherin function in prostate cancer. Int J Cancer 74: 374-377

Virtanen SS, Vaananen HK, Harkonen PL, Lakkakorpi PT (2002) Alendronate inhibits invasion of PC-3 prostate cancer cells by affecting the mevalonate pathway. Cancer Res 62: 2708-2714

Voura EB, Sandig M, Siu CH (1998) Cell-cell interactions during transendothelial migration of tumor cells. Microsc Res Tech 43: $265-275$ 